\title{
DEFINING KNOWLEDGE MANAGEMENT STRATEGY IN INDONESIAN GOVERNMENT: CASE STUDY HEAD OFFICE OF BADAN KEPEGAWAIAN NEGARA
}

\author{
Elin Cahyaningsih, Dieny Sukmiati, Nur Chasanah, and Dana Indra Sensuse
}

Faculty of Computer Science, Universitas Indonesia, Kampus Baru UI Depok, Jawa Barat, 16424, Indonesia

Email: elin.cahyaningsih@ui.ac.id

\begin{abstract}
Knowledge Management (KM) became a new concept of organizational development. Many organization starts to implement knowledge management including government. First step for implementing KM in organization is defining KM strategy. This research aims to define KM strategy byKM assessment from organization vision, mission and goals using balanced scorecard (BSC) methods to find KM performance indicator in each aspect of balanced scorecard variable. This study constructs SPSS (Statistical Package for the Social Sciences) for processing and data analysis. The authors spread questionnaire at Head Office of Badan Kepegawaian Negara, Jakarta. The result of this research are KM strategies for implementing KM in Indonesian Government case study at Badan Kepegawaian Negara are monitoring program performance in order to create a working relationship and good personnel management as a learning activity for increasing organizational performance, raise up a teamwork culture within organization in to support business process in order to reach organizational performance and competitive advantage, increasing timeliness of service target achievement and standard time of customer service in order to increase organizational performance, and increasing the coordination effectiveness of program planning and budget as to increase the accountability of the organization, performance achievement and organizational performance.
\end{abstract}

Keywords: Knowledge Management Strategy, Knowledge Management Assessment, Balanced Scorecard.

\begin{abstract}
Abstrak
Knowledge Management (KM) menjadi sebuah konsep baru dalam pengembangan organisasi. Banyak organisasi mulai mengembangkan knowledge management termasuk pemerintahan. Langkah pertama dalam penerapan knowledge management adalah menentukan strategi knowledge management. Penelitian ini ditujukan untuk menentukan strategi knowledge management dengan menggunakan assessment knowledge management melalui visi, misi dan tujuan organisasi dengan menggunakan metode balanced scorecard (BSC) untuk menemukan indikator knowledge management performance di setiap aspek variabel balanced scorecard. Penelitian ini disusun dengan menggunakan SPSS (Statistical Package for the Social Sciences) dalam pengolahan dan analisis data. Penulis menyebarkan kuisioner di Kantor Pusat Badan Kepegawaian Negara, Jakarta. Hasil dari penelitina ini adalah strategi knowledge management dalam penerapan KM di pemerintah Indonesia dengan study kasus Badan Kepegawaian Negara yaitu program pengawasan dalam rangka untuk menciptakan hubungan kerja dan manajemen kepegawaian yang baik sebagai aktivitas pembelajaran untuk meningkatkan performa organisasi, membangun budaya kerja tim dalam organisasi untuk mendukung proses bisnis internal dalam rangka mewujudkan performa dan keunggulan kompetitif organisasi, meningkatkan ketepatan pencapaian target waktu layanan dan menentukan standar waktu layanan pelanggan dalam rangka meningkatkan performa organisasi, dan yang terakhir adalah menciptakan koordinasi yang efektif dalam perencanaan program dan anggaran untuk meningkatkan akuntabilitas organisasi dan pencapaian kinerja dan performa organisasi.
\end{abstract}

Kata Kunci: Knowledge Management Strategy, Knowledge Management Assessment, Balanced Scorecard.

\section{Introduction}

Menteri Pendayagunaan Aparatur Negara dan Reformasi Birokrasi (MENPAN \& RB) was announc- ed PERMENPAN No. 14 Tahun 2011 about KM Implementation for each ministry in Indonesia. Therefore each ministry tried to change their management into knowledge management based in or- 
der to implement KM. Change management contribute to KM it's begin with change their organization vision and mission, organization goal strategy which is align with KM to build KM strategy.

This research will be explaining about the KM strategy in government. All steps to build and find KM strategy within government organization. In order to reach research objective, the literature review about knowledge management assessment, knowledge management strategy, and balanced scorecard will be define clearly. All indicators of balanced scorecard assessment were constructed as KM performance measurement indicators which used for build KM strategy in organization. These indicators were constructed and measured using SPSS to defined the main KM strategy.

The questionnaires were spread to Pegawai Negeri Sipil (PNS) of Badan Kepegawaian Negara (BKN) Jakarta. There are 67 PNS filled the research instrument. The author choose this government ministry because Badan Kepegawaian Negara has already start to implement KM by change their vision, mission and organization goal strategy into knowledge management based.

\section{Knowledge Management Assessment}

Assessment of knowledge assets also can be deined as a process of collecting, analysis and communication of qualitative and quantitative information about the organization's knowledge assets [1]. There are some reason to conduct KM assessment, such as identify and map intangible asset, identify flow of knowledge in organization, prioritize critical knowledge issue, accelerate organization learning process, identify and spread best practice, understand how knowledge creates interrelationship, understand organization social networks and identify change agent, increase innovation, increase collaborative activity and knowledge sharing culture as result awareness of benefit KM, increase motivation and create performance based culture [2].

Beccera explain that why we need to assess knowledge management because it would not be possible to determine where improvements are needed, helps establishing a baseline for implementing KM solutions, helps understand whether costs of KM efforts are justified, helps identify the gap in KM efforts and help make a case for more investment into KM [3].

\section{Knowledge Management Strategy}

Strategies are steps to achieving long-term goals in the future. Organization strategy can define as a plan that ensures the development of organizational initiative. Knowledge management strategies express alignment of organization vision, mis- sion and strategy within organization knowledge resources and capabilities to reached organization goal achievement [4]. Knowledge management strategy is a plan that describes how to manage knowledge better for the benefit of the organization based on organization vision and mission [5].

\section{Balanced Scorecard}

The balanced scorecard is the study result done by Kaplan and Norton in the year 1990 for an evaluation program to the future enterprise performance results. Because the information age requires a new evaluation indicator to measure intangible assets and knowledge assets, however, the traditional accounting and financial indicators still have reference value, which cannot be ignored. Therefore, the best option is to integrate the financial indicators and non-financial indicator.

Kaplan and Norton explain that balanced scorecard aims to connect KM measurement strategy and organizational business goals [6]. Balanced scorecard have four perspectives, there are:

TABLE 1

B ALANCE SCORECARD VARIABLE INDICATOR FOR KNOWLEDGE MANAGEMENT

\begin{tabular}{|c|c|c|c|}
\hline & $\begin{array}{l}\text { Financial }(\mathrm{F}) \\
{[7][8][10][3]}\end{array}$ & \multicolumn{2}{|c|}{$\begin{array}{c}\text { Internal Bussiness Process } \\
\text { (I) } \\
{[7][8][10][3]}\end{array}$} \\
\hline F1 & $\begin{array}{l}\text { :Performance } \\
\text { achievement }\end{array}$ & I1 & : Information share \\
\hline $\mathrm{F} 2$ & : Commitment & 12 & : Discussion \\
\hline F3 & : Time & 13 & : Infrastructure \\
\hline $\mathrm{F} 4$ & : SOP & 14 & : Data resource \\
\hline F5 & : Program Plan & 15 & : Direction \\
\hline \multirow[t]{7}{*}{ F6 } & : Budget & 16 & : KM process \\
\hline & & 17 & : Socialization \\
\hline & & I8 & $\begin{array}{l}\text { : Changes in business } \\
\text { process }\end{array}$ \\
\hline & & I9 & : Innovation \\
\hline & & I10 & : Execution time \\
\hline & & I11 & $\begin{array}{l}\text { Team work in } \\
\text { business process }\end{array}$ \\
\hline & & I12 & $\begin{array}{l}\text { : Bussiness process } \\
\text { performance }\end{array}$ \\
\hline \multirow{2}{*}{\multicolumn{2}{|c|}{$\begin{array}{c}\text { Learning \& Growth (LG) } \\
{[7][8][10][3]}\end{array}$}} & \multirow{2}{*}{\multicolumn{2}{|c|}{$\begin{array}{l}\text { Customer (C) } \\
{[7][8][10][3]}\end{array}$}} \\
\hline & & & \\
\hline LG1 & $\begin{array}{l}\text { : Human Resource } \\
\text { Development }\end{array}$ & \multirow{2}{*}{\multicolumn{2}{|c|}{$\begin{array}{ll}\mathrm{C} 1 & : \text { Completenes } \\
& \text { service } \\
\mathrm{C} 2 & : \text { Customer loyalty }\end{array}$}} \\
\hline LG2 & : Program team work & & \\
\hline LG3 & : Adaptability & $\mathrm{C} 3$ & infrastructure \\
\hline LG4 & $\begin{array}{l}\text { Ability to follow } \\
\text { change }\end{array}$ & $\mathrm{C} 4$ & $\begin{array}{l}: \text { Infrastructure } \\
\text { utilization }\end{array}$ \\
\hline LG5 & $\begin{array}{l}\text { Monitoring } \\
\text { program }\end{array}$ & C5 & \multirow{3}{*}{$\begin{array}{l}: \text { Infrastructure } \\
\text { reliability } \\
: \text { Customer intimate } \\
: \text { Team work and } \\
\text { service responsibility }\end{array}$} \\
\hline LG6 & : Evaluating program & C6 & \\
\hline LG7 & $\begin{array}{l}\text { Learning } \\
\text { infrastructure }\end{array}$ & $\mathrm{C} 7$ & \\
\hline LG8 & : Employee & $\mathrm{C} 8$ & $\begin{array}{l}: \text { Timeliness of } \\
\text { service }\end{array}$ \\
\hline LG9 & : Reward & & \\
\hline LG10 & $\begin{array}{l}\text { Employee } \\
\text { competition }\end{array}$ & & \\
\hline
\end{tabular}


Financial

Centered on profitability, include measures such as operating income, return on capital employed and economic value added.

\section{Customer}

Indentify of expected results of the business strategies, include customer satisfaction, retention and market share.

\section{Internal business process}

Include process innovation, operation and after sales service.

Learning and growth

Include employee capability and organizational alignment.

Balanced scorecard also claim as a tool for measure KM performance and help manager to built KM strategy [7][8]. Balanced scorecard strategic map is a framework that view a relationship between each component of an organization's strategy from four BSC perspective (financial, customer, internal business process and learning and gr owth) [9]. Table 1 outlined the result of literature study for balanced scorecard variable instrument for knowledge management:

\section{Methodology}

Based on previous studies, the author defines the executive steps of research as seen in figure 2 below:
These executive steps are writing the previous study related to the theoretic and literature of knowledge management strategy, knowledge management assessment and balanced scorecard. Next steps are find the vision, mision and organization goals of Badan Kepegawaian Negara, which are show below:

Vision of Badan Kepegawaian Negara: "Menjadi Pembina dan Penyelenggara Manajemen Kepegawaian yang Professional dan Bermartabat Tahun 2025"; "Became a founder and administrator of professional and dignified human resource in 2025 ".

Mision of Badan Kepegawaian Negara: 1) mengembangkan sistem manajemen kepegawaian negara (to develop government human resource system); 2) mengembangkan sistem pelayanan kepegawaian (to develop human resource service system); 3) mengembangkan manajemen internal BKN (to develop internal management of BKN)

BKN strategic goals: 1) mewujudkan Manajemen Kepegawaian yang Modern (to create modern human resource management); 2) mewujudkan Pelayanan Prima Bidang Kepegawaian (to create excellent service in human resource);3) mewujudkan Manajemen Internal yang Efektif, Efisien, dan Akuntabel (to create effective, efficient and accountable internal management).

Aligning balanced scorecard variable indicator with organization $\mathrm{KM}$ performance measurement (4 perspective variable of BSC). This steps are used for align each variable indicator from vision, mission and organization goals into four BSC perspective by identifying and classifying each va-

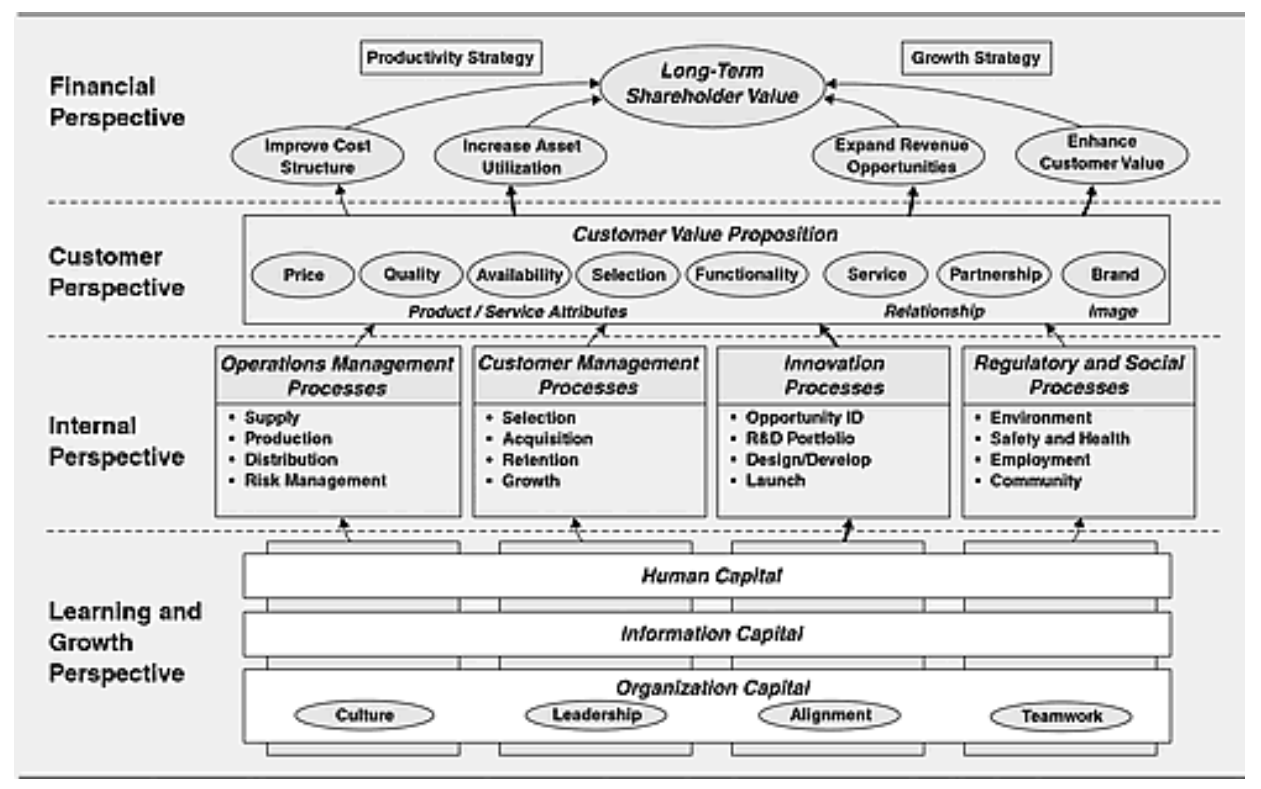

Figure 1. Strategy Map Kaplan \& Norton 


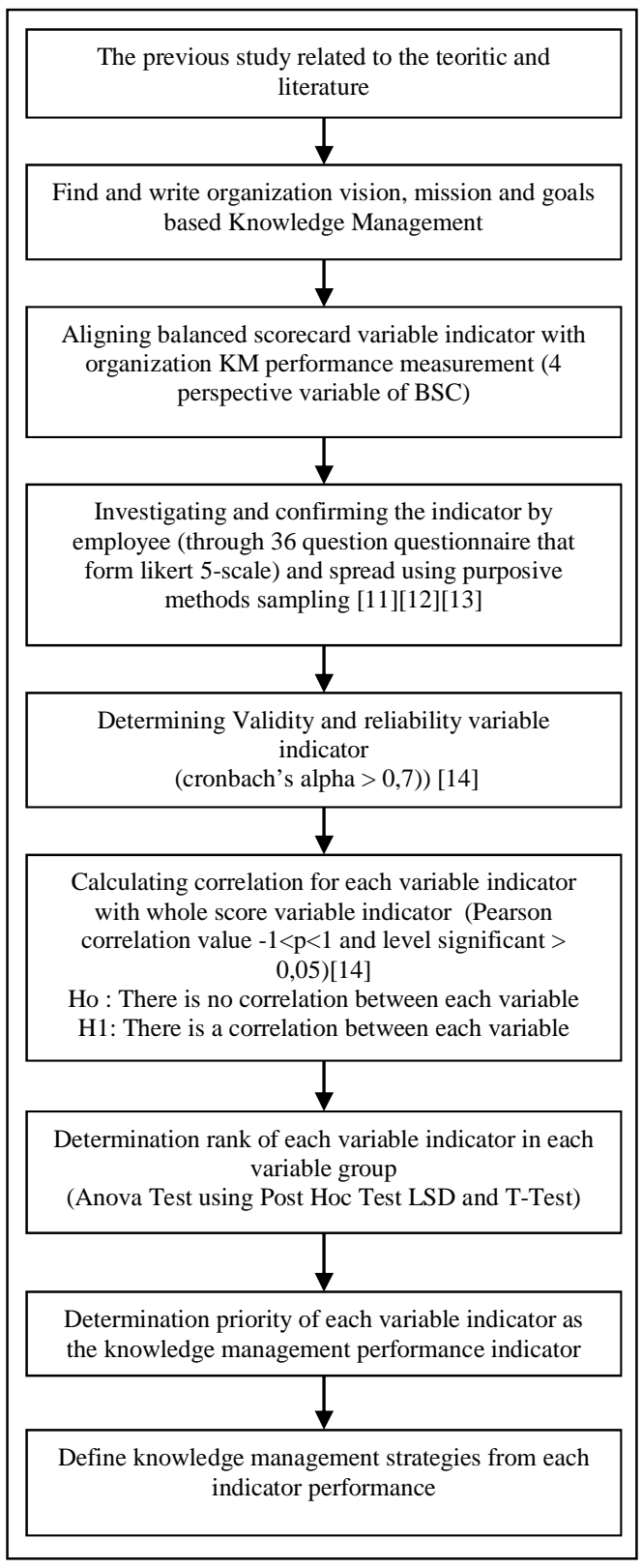

Figure 2. Executive steps of Knowledge Management Strategy

riable indicators. These variable indicators are used for making statement in the questionnaire.

Investigating and confirming the indicator by employee (through 36 question questionnaire that form likert 5-scale) and spread using purposive methods sampling. Likert 5-scare are design to collect data with 5 interval of level agreement, favorability or other similar perception from respondent [11]. These questionnaire are spread among the employyee in head office of Badan Kepegawaian Negara using purposive methods sampling, which is non- random informant selection technique to find out sample people that can and willing to provide the information by fill in the questionnaire [13]. Determining Validity and reliability variable indicator with using cronbach's alpha index $>0,7$ which is determine the consistency of the test item and estimate measurement [15].

Calculating correlation for each variable indicator with whole score variable indicator using Pearson correlation which value $-1<\mathrm{p}<1$ and level significant $>0,05$ for this hypothesis:

Ho: There is no correlation between each variable $\mathrm{H} 1$ : There is a correlation between each variable Pearson correlation coefficient is used for assess each variable correlation to predict each other [14].

Determination rank of each variable indicator in each variable group (Anova Test) using Post Hoc Test LSD and T-Test is used to rank the variable indicator in each variable measurement in BSC methods. These rank of variable indicator are used for determining priority of each variable indicator as the knowledge management performance indicator which can choose by the author as a knowledge management strategies.

\section{Result and Analysis}

The author spread a questionnaire into 67 employees in Badan Kepegawaian Negara Jakarta which demography is shown below:

Spread questionnaire $=85$

Questionnaire were receive $=67$

Questionnaire were not return $=18$

The result of each steps of defining knowledge management strategies are shown in the Table 2.

Table 2 shows that each of the variables tested are valid and reliable because it has a Cronbach's Alpha value greater than 0.7 . Thus, all indicators contained in each variable is valid and reliable.

\section{TABLE 2}

VALIDITY AND RELIABILITY TEST

\begin{tabular}{ccc}
\hline Variabel & Cronbach's Alpha & Jumlah Indikator \\
\hline Financial & 0,748421790974977 & 6 \\
Internal Bussiness & 0,825250495369519 & 12 \\
Process & & 10 \\
Learning \& Growth & 0,802436010017231 & 8 \\
Customer & 0,812107688576278 & 8 \\
\hline
\end{tabular}

TABLE 3

PEARSON CoRrelation Test FOR FinANCIAL VARIABLE

\begin{tabular}{cc} 
PEARSON CORRELATION TEST FOR FINANCIAL VARIABLE \\
\hline Indicator & Financial \\
\hline F1 &, $835^{\text {*** }}$ \\
F2 &, $634^{\text {*** }}$ \\
F3 &, $643^{\text {*** }}$ \\
F4 &, $614^{* * *}$ \\
F5 &, $644^{\text {*** }}$ \\
F6 &, $620^{\text {*** }}$ \\
\hline
\end{tabular}


Table 3, Table 4, Table 5, and Table 6 shows that each indicator of each variable has a correlation value greater than -1 and smaller than 1 . This shows that each indicator in each variable has a relationship with each other. The relationship of each indicator inside variable is needed to determine which indicator that have an impact on variable. If the indicator does not have an impact on the variable, the indicator can be omitted.

TABLE 4

PEARSON CORRELATION TEST FOR INTERNAL BUSSINESS PROCESS VARIABLE

\begin{tabular}{cc}
\hline Indikator & Internal Bussiness Process \\
\hline I1 &, $643^{* * *}$ \\
I2 &, $685^{* *}$ \\
I3 &, $583^{* *}$ \\
I4 &, $498^{* *}$ \\
I5 &, $541^{* *}$ \\
I6 &, $573^{* *}$ \\
I7 &, $579^{* *}$ \\
I8 &, $616^{* *}$ \\
I9 &, $661^{* *}$ \\
I10 &, $628^{* *}$ \\
I11 &, $577^{* *}$ \\
I12 & $441^{* *}$ \\
\hline
\end{tabular}

TABLE 5

PEARson Correlation TEST FOR LEARNING AND GROWTH VARIABLE

\begin{tabular}{cc}
\hline \multicolumn{2}{c}{ LARIABLE } \\
\hline Indikator &, $595^{* *}$ \\
LG1 &, $690^{* *}$ \\
LG3 &, $537^{* *}$ \\
LG4 &, $582^{* *}$ \\
LG5 &, $637^{* *}$ \\
LG6 &, $573^{* *}$ \\
LG7 &, $689^{* *}$ \\
LG8 &, $512^{* *}$ \\
LG9 &, $444^{* *}$ \\
LG10 &, $758^{* *}$ \\
\hline
\end{tabular}

Based on SPSS analysis, the result of the KM performance indicator in each variable are team work in business process for internal business process variable, monitoring program for learning and growth variable and the last one is timeliness of service for customer variable.

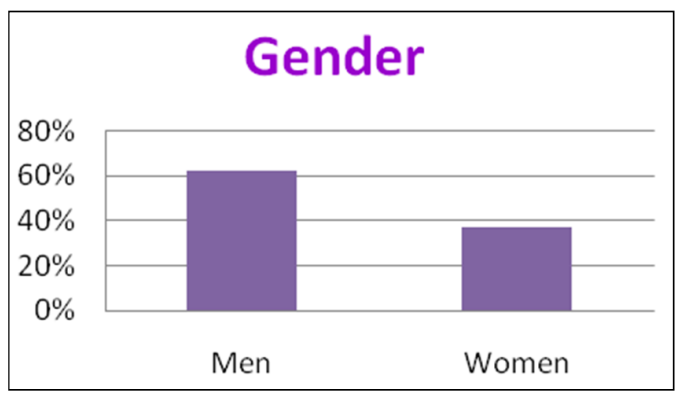

Figure 3. Demography of Gender
TABLE 6

PEARSON CORRELATION TEST FOR CUSTOMER VARIABLE

\begin{tabular}{|c|c|}
\hline Indikator & Customers \\
\hline $\mathrm{C} 1$ &, $715^{* *}$ \\
\hline $\mathrm{C} 2$ &, $776^{* *}$ \\
\hline $\mathrm{C} 3$ &, $715^{* * *}$ \\
\hline $\mathrm{C} 4$ & $669^{* *}$ \\
\hline $\mathrm{C} 5$ & $666^{* *}$ \\
\hline C6 &, $645^{* * *}$ \\
\hline C7 &, $501^{* *}$ \\
\hline $\mathrm{C} 8$ &, $586^{* * *}$ \\
\hline
\end{tabular}

TABLE 7

ANOva TEST USING POST Hoc Test LSD AND T-TEST

\begin{tabular}{|c|c|c|}
\hline Faktor & Indikator & Mean \\
\hline \multirow[t]{6}{*}{ Financial } & F5 & 4,223881 \\
\hline & $\mathrm{F} 2$ & 4,014925 \\
\hline & F4 & 4,014925 \\
\hline & $\mathrm{F} 1$ & 3,985075 \\
\hline & F3 & 3,910448 \\
\hline & F6 & 3,597015 \\
\hline \multirow[t]{12}{*}{ Internal Bussiness Process } & I11 & 3,835821 \\
\hline & $\mathrm{I} 4$ & 3,80597 \\
\hline & I7 & 3,731343 \\
\hline & $\mathrm{I} 12$ & 3,731343 \\
\hline & I6 & 3,716418 \\
\hline & I1 & 3,656716 \\
\hline & $\mathrm{I} 2$ & 3,597015 \\
\hline & I5 & 3,597015 \\
\hline & I9 & 3,492537 \\
\hline & $\mathrm{I} 3$ & 3,462687 \\
\hline & $\mathrm{I} 10$ & 3,343284 \\
\hline & I8 & 3,059701 \\
\hline \multirow[t]{10}{*}{ Learning \& Growth } & L5 & 3,865672 \\
\hline & L6 & 3,835821 \\
\hline & L3 & 3,746269 \\
\hline & L2 & 3,716418 \\
\hline & L4 & 3,716418 \\
\hline & L9 & 3,686567 \\
\hline & L7 & 3,671642 \\
\hline & L8 & 3,641791 \\
\hline & $\mathrm{L} 1$ & 3,61194 \\
\hline & L10 & 3,454545 \\
\hline \multirow[t]{8}{*}{ Customers } & $\mathrm{C} 8$ & 3,865672 \\
\hline & C6 & 3,671642 \\
\hline & $\mathrm{C} 7$ & 3,671642 \\
\hline & $\mathrm{C} 1$ & 3,552239 \\
\hline & $\mathrm{C} 3$ & 3,507463 \\
\hline & $\mathrm{C} 2$ & 3,492537 \\
\hline & $\mathrm{C} 4$ & 3,477612 \\
\hline & C5 & 3,41791 \\
\hline
\end{tabular}

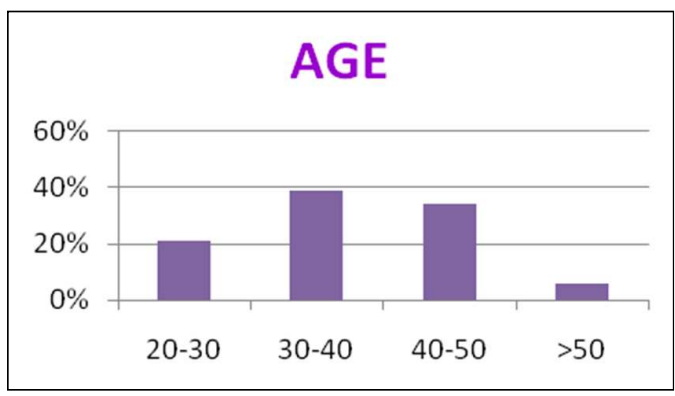

Figure 4. Demography of Age 
These KM performance indicator priority are used for define the knowledge management strategies in Indonesian Government case study Badan Kepegawaian Negara Jakarta. The KM strategies are shown below:

After some variable indicator construct in this research and became the knowledge management strategies, the explanation of each strategies are describe clearly in this section.

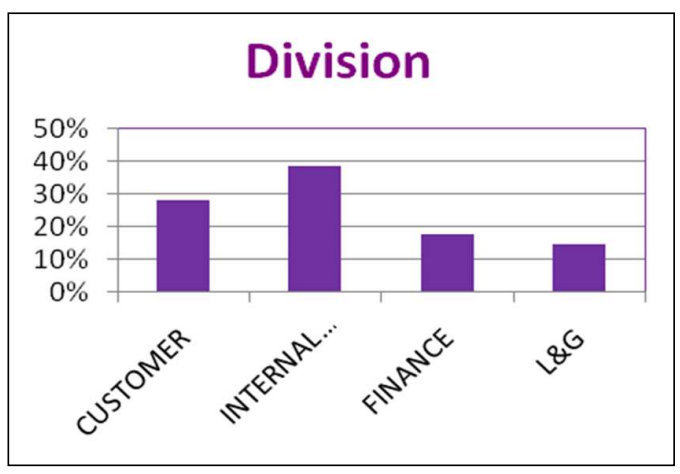

Figure 5. Demography of Division

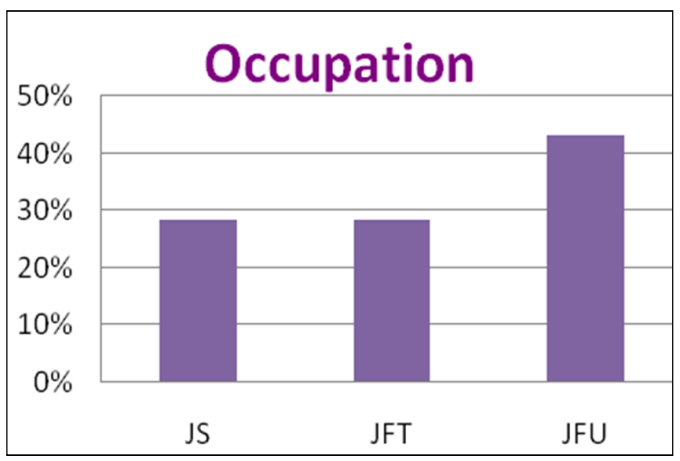

Figure 6.Demography of Occupation

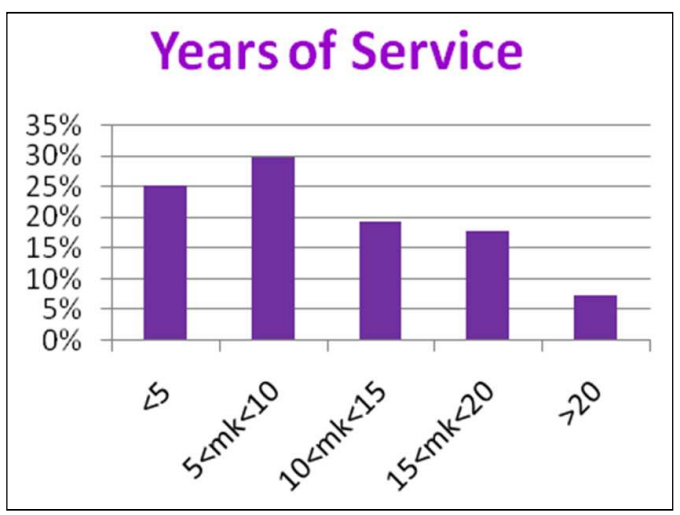

Figure 7. Demography Year of Service
Monitoring Program Performance

Monitoring program performance in order to create a working relationship and good personnel management as a learning activity for increasing organizational performance.

\section{Monitoring Every Program}

Monitoring every program is really important because both supervision and worker can have a good working relationship during the working activity, they can share and find a good solution for the best result.

\section{Raise up a Team Work Culture}

Raise up a team work culture within organization to support business process in order to reach organizational performance and competitive advantage.

Organization should build a team work culture in each organizational aspect, because with this culture all organization initiatives can be achieved more easily because each organization member have the same goals and the same responsibility for increasing organizational performance.

Increasing Timeliness of Service

Increasing timeliness of service target achievement and standard time of customer service in order to increase organizational performance.

Time of service became one of the measurement indicator for customer, therefore organization should aware about this and have to make a target and standard for time of service as of their successful factor.

Increasing the Coordination Effectiveness Increasing the coordination effectiveness of program planning and budgeting as to increase the accountability of the organization, performance achievement and organizational performance.

The organization should have a good program planning and budgeting based on operational standard and procedure to reach the organization goals. The best program plan must be accountable and have impact to organization goals.

\section{Conclusion}

Based on some literature studies conducted in this research, there were 4 (four) knowledge management strategies that can be determine such as increasing the coordination effectiveness of program planning and budgeting as to increase the accounttability of the organization, performance achievement and organizational performance, raise up a team work culture within organization to reach organizational performance and competitive advantage, monitoring program performance in order to create a working relationship and good personnel mana- 


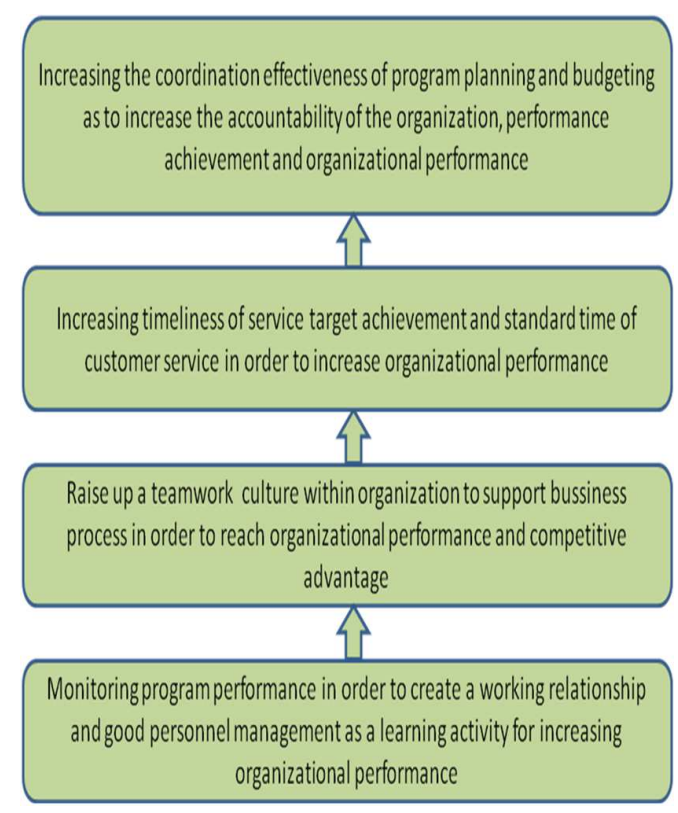

Figure 8. Knowledge Management Strategy

gement for increasing organizational performance and increasing timeliness of service target achievement and standard time of customer service in order to increase organizational performance.

In the future this research can be develop using another knowledge management assessment method and with a large sample respondent also more than one case study.

\section{References}

[1] Lerro, Antonio, Francesca A. Iacobone and Giovanni Schiuma "Knowledge assets assessment strategies:organizational value, processes,approaches and evaluation architectures. "Journal of Knowledge Management. Emerald, 2012. 563-575

[2] Rao, M. Overview: The Social Life of KM Tools. In Knowledge Management Tools and Techniques: Practitioners and Experts Evaluate KM Solutions. Oxford: Elsevier Butterworth - Heinemann, 2005.

[3] Fernandez, Irma Becerra and Rajiv Sabherwal. Knowledge Management Systems and Processes. New York: M.E Sharpe, 2010.

[4] MohdZin, Ida Nianti and Charles Egbu. "Readiness of Organizations to Implement a Knowledge Management Strategy: A Construc- tion Industry Overview." Proceding $26^{\text {Th }}$ Annual ARCOM Confrernce, 6-8 September 2010, Leeds, UK., Association of Researcher in Construction Management. 2010. 789-798.

[5] Zack, Micheal H. "Developing A Knowledge Strategy." California Management Review (1999): 125 - 145.

[6] Kaplan, R. S. and D. P. Norton. The Balanced Scorecard: Translatting Strategy into Action. Boston: Harvard Business School Press, 1996.

[7] Xianyou, Zhu. "A Novel Knowledge Management Performance Assessment Method based on Balance Scorecard." 2nd Conference on Environmental Science and Information Application Technology.IEEE， 2010.691694.

[8] YIN, Qing-Wei. "Performance Model of Knowledge Workers based on Balanced Scorecard." IEEE (2011): 2143 - 2144.

[9] Kaplan, R. S. and D. P. Norton. Strategy Maps. Converting Intangible Assest into Tangible Uutcomes. Boston: Harvard Business School Press, 2004.

[10] Fairchild, Alea M. "Knowledge Management Metrics via Balanced Scorecard Methodology." 35th Hawaii International Conference on System Science.Hawai: IEEE, 2002. 1-8.

[11] Balasubramanian, N. "Likert Technique of Attitude Scale Construction in Nursing Research." Asian J. Nursing Edu.and Research (2012): 65-69.

[12] Tongco, MA. Dolores C. Purposive Sampling as a Tool for Informant Selection. A Journal of Plants, People and Applied Research. Etnobotany Research and Applications. (2007); 147-158.

[13] Likert, Rensis. "A Technique for the measurement of attitude. "Archives of Psychology (1932): 5-54.

[14] Perner, Lars E. Using SPSS/PC+ to Analyze Research Data.Likert, Rensis. "A Technique for the measurement of attitude. "Archives of Psychology (1932): 5-54.

[15] Gadermann, Anne M., Martin Guhn and Bruno D. Zumbo. Estimating Ordinal Reliability for Liket-type and Ordinal Item Response Data: A conceptual, Empirical and Practical Guide. Practical Assessmnet, Research and Evaluation. Volume 17, Number 3, Januari (2012): 1 - 13 . 


\section{Appendix}

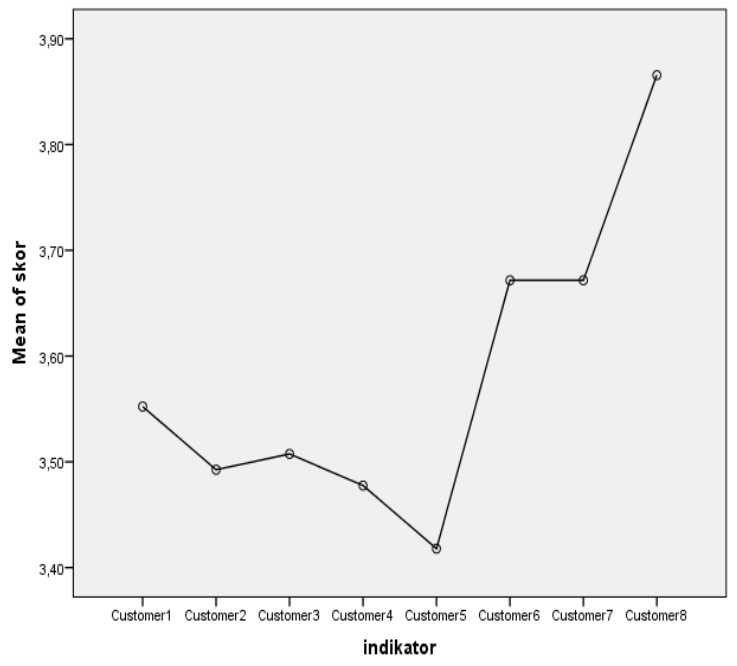

Appendix 3. Customer Indicator

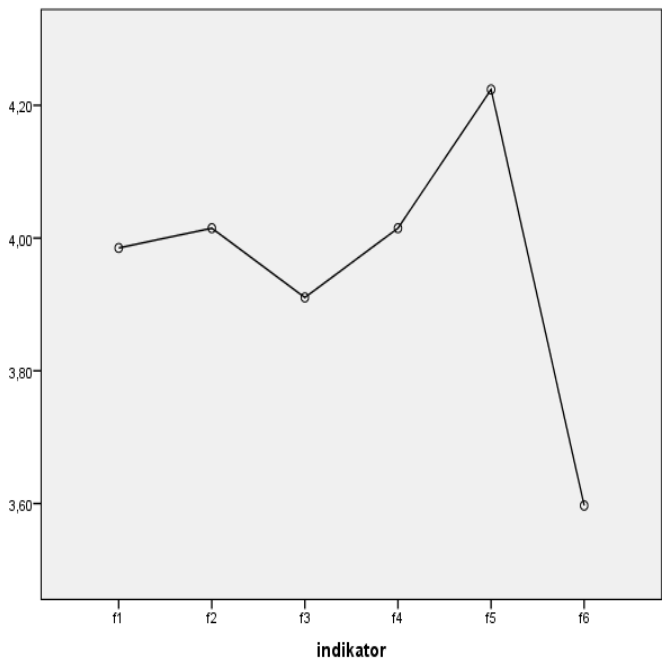

Appendix 2. Financial Indicator

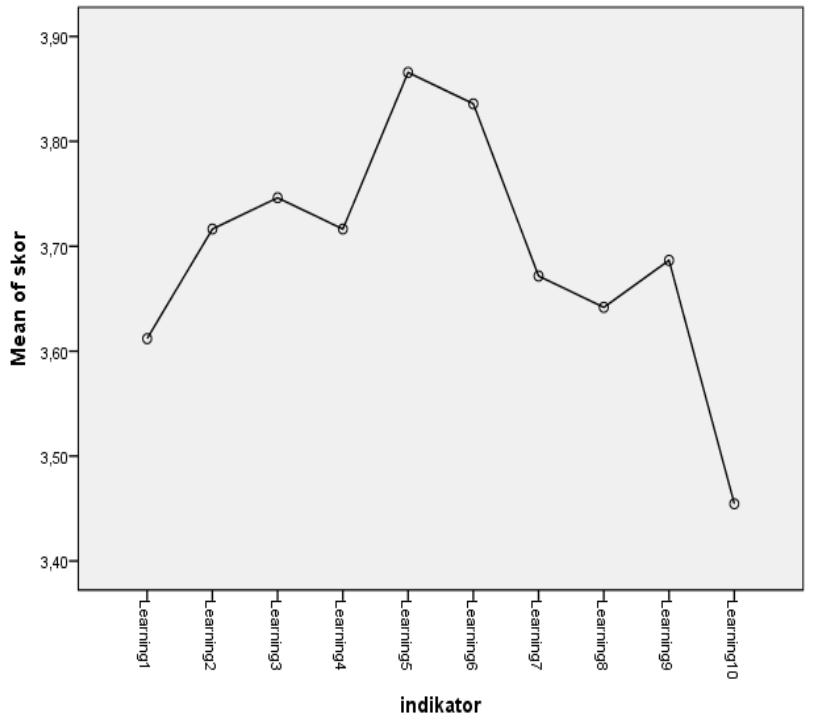

Appendix 1. Learning Indicator 